Article

\title{
Delving into the Causes and Effects of Entomopathogenic Endophytic Metarhizium brunneum Foliar Application-Related Mortality in Spodoptera littoralis Larvae
}

\author{
Inmaculada Garrido-Jurado *(D), David Montes-Moreno, Pilar Sanz-Barrionuevo \\ and Enrique Quesada-Moraga \\ Department of Agronomy, ETSIAM, University of Cordoba, Campus de Rabanales, Edificio C4 Celestino Mutis, \\ 14071 Cordoba, Spain; g32momod@uco.es (D.M.-M.); g32sabam@uco.es (P.S.-B.); cr2qumoe@uco.es (E.Q.-M.) \\ * Correspondence: g72gajui@uco.es; Tel.: +34-957218475
}

Received: 5 June 2020; Accepted: 7 July 2020; Published: 9 July 2020

check for updates

\begin{abstract}
The aim of the current study was to delve into the causes of mortality of Spodoptera littoralis larvae feeding on Metarhizium-colonized plants in the absence of fungal outgrowth on the cadavers as previous studies reported and to elucidate the possible indirect effects of this fungus-colonized diet. The effect was evaluated in experiments conducted using leaf discs of colonized plants and in planta using fungus-colonized whole plants. The mortality rates of larvae fed on Metarhizium-colonized melon leaves were $45.0 \%$ and $87.5 \%$, and the average survival times were 6.6 and 3.1 days in experiments performed with discs and in planta, respectively. Notably, these mortality levels were not associated with observed apoptosis mediated by caspases 1, 3-7 and 8; thus, further investigation into the possible immune system reaction of the insect after the ingestion of colonized plants is required. The leaf consumption of S. littoralis larvae fed on melon-colonized leaves was lower than that on control plants in the disc experiments but not in experiments conducted in planta. In this regard, in experiments performed in planta, plant damage increased larval mortality in both fungally challenged and control larvae. There was also a meaningful effect of exposure to Metarhizium-colonized melon leaf discs on S. littoralis fitness, with significant reductions in $39.0 \%$ and $22.0 \%$ in female fecundity and egg fertility, respectively, detected in females emerging from pupae developing from larvae surviving exposure to colonized plant discs; all larvae died in the in planta experiments. Hence, the present work presents new findings revealing the high potential of endophytic entomopathogenic fungi to improve the outcome of foliar applications against chewing insects in the short, mid-and long term, by the reduction of the reproductive potential of surviving adults and reveals new insights into the development of bioassays with whole plants for more detailed evaluation of the impact of these fungi as endophytes used for plant protection.
\end{abstract}

Keywords: ascomycete; mycoinsecticide; cotton leafworm; fitness; caspase; tritrophic interaction

\section{Introduction}

The use of entomopathogenic fungi (EPFs) in integrated pest management programs as an alternative to less environmentally benign alternatives, such as chemical insecticides, is becoming more frequent [1]. EPFs are contact action microbials that are normally applied via spray application directed at the plant canopy targeting a pest; depending upon the endophytic behavior of the fungal strain, this may lead to temporary colonization of the leaves that improves the outcome of foliar applications of mycoinsecticides against piercing-sucking and chewing insects [2,3]. Strategies such as soil treatments and seed dressing, can also take advantage of EPF endophytic behavior, potentially leading to the 
systemic protection of the plant against insect and mite pests [1,4]. In this regard, both temporary and permanent endophytic colonization has provided successful control of boring, chewing, and sucking insects $[1-3,5,6]$.

The polyphagous cotton leafworm, Spodoptera littoralis (Boisduval) (Lepidoptera: Noctuidae), is distributed worldwide and can feed on more than 100 host plants, potentially producing yield losses of 50\% related to its larval foliage consumption activity [7-9]. Its control is becoming more difficult due to resistance and cross-resistance to chemical insecticides and to the bioinsecticide Bacillus thuringiensis Berliner $[10,11]$. However, the use of EPFs and the insecticidal compounds they produce has shown promise against this harmful lepidopteran in both foliar- or soil-dwelling stages and exhibits compatibility with nontarget organisms, including natural enemies [3,12-17]. To date, there are many studies that report the success of using different genera of EPF (Metarhizium anisopliae (Metsch.), Beauveria bassiana (Balsamo) Vuill., Cordyceps fumosorosea (Wize) Kepler, B. Shrestha \& Spatafora among others) for controlling different stages of S. littoralis [18-20], but only a few have focused on the new role of EPF as an endophyte for control of this pest [3,7,17].

Notably, S. littoralis larvae and larvae from other lepidopterans that die after being fed plants endophytically colonized with EPFs rarely show any signs of fungal outgrowth, with the possible causes of mortality and effects on pest fitness remaining unknown $[3,17,21]$. Indeed, recent studies addressing EPF-arthropod interactions have reported that the EPFs may induce arthropod death without the classical fungal infection process involving conidial adhesion, germination and penetration through the cuticle. For example, the ingestion of Metarhizium sp. conidia by mosquito larvae and the aquatic crustaceans Daphnia pulex and Artemia magna induces high levels of stress gene expression and stress-mediated caspase activation, which are the cause of their death, rather than fungal colonization [22-24]. Similarly, the mechanical damage caused to the plant when obtaining leaf discs for experiments may result in the loss of volatiles and production of secondary metabolites and enzymes that modify the fitness and behavior of insects $[25,26]$, which could occur in bioassays in which EPF-colonized leaf discs are offered to lepidopterans [25]. The aim of the present work was to explore the effects of feeding S. littoralis larvae on Metarhizium-colonized melon leaves on their mortality and leaf consumption and the fecundity and fertility of the adults developing from surviving larvae. In addition, this work examines the possible causes of $S$. littoralis mortality after feeding on Metarhizium-colonized plants, with an emphasis on plant defense- and host defense-related mechanisms such as apoptosis.

\section{Materials and Methods}

\subsection{Insects}

Spodopera littoralis larvae were obtained from a stock colony from the Department of Agronomy of the University of Cordoba (Spain). The larvae were maintained at $26 \pm 2{ }^{\circ} \mathrm{C}$ under $70 \pm 5 \% \mathrm{RH}$ and a photoperiod of 16:8 (L:D) h, and they were fed an artificial diet as described by Santiago-Álvarez [27].

\subsection{Fungal Strain}

Metarhizium brunneum strain EAMb 09/01-Su was obtained from the culture collection at the Department of Agronomy of the University of Cordoba (Spain). This strain was originally isolated from the soil of a meadow forest system in Castilblanco de los Arroyos (Seville, Spain). The strain was deposited in the Spanish collection of culture types (CECT) with accession number CECT 20784. Cultivation and inoculum production for the laboratory and field experiments were performed as described by Garrido-Jurado et al. [2]. This strain was selected due to both its high virulence towards S. littoralis and its endophytic behavior [3]. 


\subsection{Colonization of Melon Plants}

Melon seeds (galia variety) were disinfected by immersion in $70 \%(v / v)$ ethanol for $2 \mathrm{~min}$, followed by $2 \% \mathrm{NaOCl}$ (Sigma-Aldrich, St. Louis, MO, USA) for $5 \mathrm{~min}$. Then, they were transferred to plastic pots with 110 wells $(25 \times 25 \times 25 \mathrm{~mm})$ containing the sterilized substrate "Compo Sana plantation" (Compo GmbH, Münster, Germany). One seed was sown per pot, and the pots were maintained at a temperature of $27 \pm 3{ }^{\circ} \mathrm{C}$ under $14 \mathrm{~h}$ of daylight (light intensity of $700 \mathrm{~lx}$ ) and $10 \mathrm{~h}$ of darkness. The plants were subsequently transplanted to individual pots $(70 \times 70 \times 60 \mathrm{~mm})$ containing $300 \mathrm{~g}$ of sterilized substrate and maintained at $26 \pm 5^{\circ} \mathrm{C}$ with a $14: 10 \mathrm{~h}$ photoperiod.

For experiments with discs, a fungal suspension of $10^{8}$ conidia $\mathrm{mL}^{-1}$ with $0.1 \%$ Tween 80 was sprayed on 6 true-leaf plants with an aerograph 27085 (piston compressor of $23 \mathrm{~L} / \mathrm{min}, 15-50$ PSI and $0.3 \mathrm{~mm}$ nozzle diameter, Artesanía Latina S.A., Lamadrid, Spain). The leaves were sprayed with $2 \mathrm{~mL}$ of the fungal suspension, and the soil was covered with aluminum foil to avoid the run-off of the suspension. Thereafter, the plants were covered with a transparent plastic sheet to promote fungal growth for $48 \mathrm{~h}$. Control plants were sprayed with sterile water with $0.1 \%$ Tween 80 . For in-planta experiment, one leaf per plant was brushed with a fungal suspension $\left(10^{8}\right.$ conidia $\mathrm{mL}^{-1}$ with $0.1 \%$ Tween 80 ), and the control was brushed with sterile water with $0.1 \%$ Tween 80 . The leaves were then covered with a transparent plastic bag to promote fungal growth for $48 \mathrm{~h}$ (Figure 1).
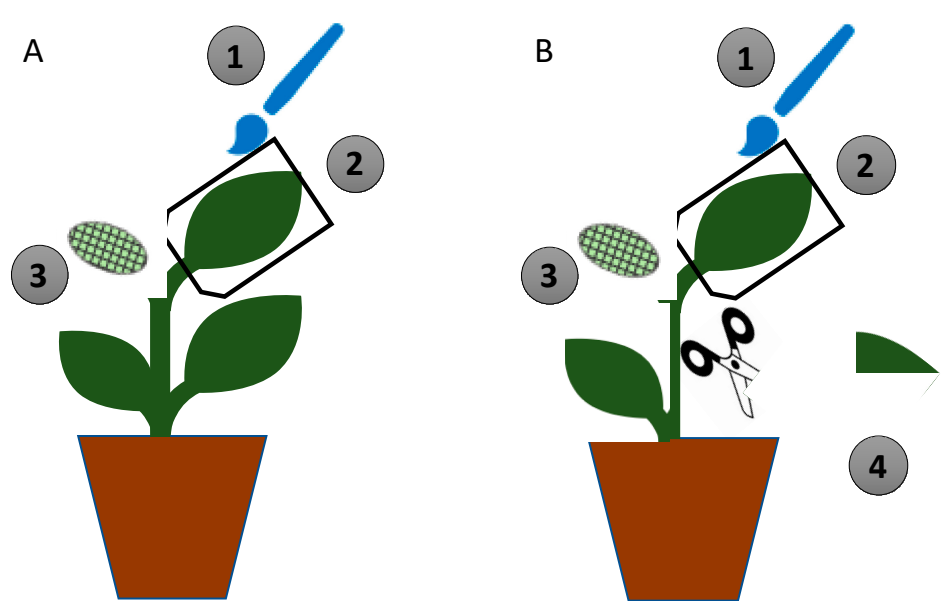

Figure 1. Design of the in-planta experiment. (A) Non-damaged plant; (B) damaged plant. (1) One leaf was brushed with the fungal suspension (treated) or sterile water with $0.1 \%$ Tween 80 (control). (2) The leaf was covered with a transparent plastic bag for $48 \mathrm{~h}$. (3) Four $\mathrm{L}_{2}$ Spodoptera littoralis larvae were clipped on a non-treated leaf at $48 \mathrm{~h}$ and left to feed on the leaf for $48 \mathrm{~h}$. (4) Damage was artificially caused by tearing a non-treated leaf at $48 \mathrm{~h}$ after fungal inoculation.

The leaves of plants colonized for $48 \mathrm{~h}$ and controls were removed from the plants and washed with a $2 \%$ aqueous solution of $\mathrm{NaOCl}$ for $5 \mathrm{~min}$, followed by two rinses of sterilized water for surface disinfection. To ensure total disinfection of the leaves, $100 \mu \mathrm{L}$ of the last rinse from each sample was cultured on malt agar (MA) plates. For the in-planta experiment, one non-treated leaf from treated and control plants was also inspected for endophytic colonization following the previous protocol. Subsequently, ten fragments per leaf $(5 \times 5 \mathrm{~mm})$ were randomly collected and placed on MA plates, ensuring full contact between fragments, and culture was performed in medium at $25^{\circ} \mathrm{C}$. Colonization was determined by counting the number of fragments showing fungal outgrowth after 7 days of incubation. To confirm the fungal infection of the fragments, the fungus was observed using a light microscope (Nikon, Tokyo, Japan) and identify its morphological features according to Seifert et al. [28]. 


\subsection{Effect of Exposure of S. littoralis to Metarhizium-Colonized Melon Discs}

Third-instar larvae of $S$. littoralis were individually fed $10-\mathrm{mm}$ colonized melon discs, while the controls were fed melon discs from control plants. The discs were previously surface-disinfected using the procedure described in Section 2.3. The discs were replaced by other fresh discs daily and then scanned to measure the amount of consumed foliar leaf. Three replicates of 10 larvae each were used per treatment, and the treatments were repeated four times. First, the direct effect on larval mortality was recorded every $24 \mathrm{~h}$ for 8 days, as was the consumed area of the melon discs. In addition, the non-direct effects that were measured included (1) apoptosis in the dead larvae based on the measurement of caspase activity using Caspase Glo 1 Inflammasome, Caspase Glo 3-7, and Caspase Glo 8 luminometric kits in accordance with the manufacturer's guidelines (Promega), as described by Garrido-Jurado et al. [24], and (2) the development of living larvae, followed until their pupation and the emergence of adults. As adults emerged, they were placed in oviposition chambers, and egg clusters were collected as described by Garrido-Jurado et al. [15]. The total numbers of eggs laid per female and newly emerged larvae were recorded.

\subsection{Effect of the in Planta Exposure of S. littoralis to Metarhizium-Colonized Melon Leaves}

One non-treated leaf of each plant that had been treated for 48 h-treated was infested with four $\mathrm{L}_{2}$ S. littoralis larvae using clip cages (Figure 1). The clip cages were removed $48 \mathrm{~h}$ post-infestation, and the larvae were placed in individual cages, as described in Section 2.4, after which they received an artificial diet. Similarly, control plants were infested with four $\mathrm{L}_{2} S$. littoralis larvae. Other 48 -h-treated plants were also infested as described above, but damage was artificially caused by tearing a non-treated leaf. The last procedure was also performed in the control plants. As in the previous treatments, clip cages were removed $48 \mathrm{~h}$ post-infestation, and the larvae were reared individually and fed an artificial diet thereafter. There were three plants per treatment and the experiment was performed twice. The leaves infested with larvae were scanned to measure the consumed area. The treated leaves and consumed leaves were surface disinfected using the procedure described in Section 2.3 and placed in MA plates to evaluate the colonization rate. Larval mortality was recorded every $24 \mathrm{~h}$ for 8 days, and the Caspase Glo 1 Inflammasome assay was followed, as in Section 2.4, since only caspase 1 is specific to lepidopterans [29].

\subsection{Statistical Analysis}

Mortality data and female fertility data were analyzed using a generalized linear model (distribution = binomial; link = logit). Female fecundity data were also modelled with a generalized linear model (distribution $=$ Poisson; link $=\log$ ) using JMP 8 software $\left(\right.$ SAS ${ }^{\circledR}$, Cary, NC, USA). Treatment comparisons were performed using the $\chi^{2}$ test $(p<0.05)$. Average survival times (ASTs) and cumulative survival ratios were obtained via Kaplan-Meier survivorship analysis and compared via the log-rank test calculated with IBM SPSS 25.0 software. Digital images of the melon discs and leaves were captured to evaluate the leaf consumption of each larva. The area of each disc/leaf was delimited using ImageJ (http://imagej.nih.gov/ij/), and the consumed area of melon discs was analyzed by analysis of variance (ANOVA) and compared using the LSD test at 5\% significance since the discs were replaced daily, following the confirmation of normality and homogeneity of variance for the raw data. The consumed areas of the leaves in the in-planta experiment were analyzed according to Kruskal-Wallis one-way nonparametric AOV analysis. All analyses of the consumed area were performed using IBM SPSS 25.0 software. 


\section{Results}

\subsection{Effect of Exposure of S. littoralis to Metarhizium-Colonized Melon Discs}

\subsubsection{Mortality and Food Consumption}

The percentage of the fungal colonization of the treated melon leaves was $64.4 \pm 6.8 \%$ at $48 \mathrm{~h}$, whereas fungal colonization was not detected in the control leaves. Significant differences in mortality $\left[\chi^{2}(1)=34.09, p<0.001\right]$ were found between larvae fed on the control and Metarhizium-colonized discs, with mortality rates of 11.7 and $45.0 \%$, respectively, and Abbott mortality of $33.3 \%$ (Table 1). The average survival times also showed significant differences and were 6.6 days for the fungal treatment and 7.5 days for the controls (Table 1). In addition, the cumulative survival ratio significantly decreased in the larvae fed melon leaves colonized by the fungus (Figure 2A).

Table 1. Effects of exposure of S. littoralis larvae to M. brunneum-colonized plants.

\begin{tabular}{|c|c|c|c|c|c|c|}
\hline & \multirow{2}{*}{\multicolumn{2}{|c|}{ Disc Assay c $^{c}$}} & \multicolumn{4}{|c|}{ In Planta Assay ${ }^{\mathrm{d}}$} \\
\hline & & & \multicolumn{2}{|c|}{ Normal Plant } & \multicolumn{2}{|c|}{ Damaged Plant } \\
\hline & $\begin{array}{c}\text { Mortality }{ }^{a} \\
(\%)\end{array}$ & $\begin{array}{l}\text { AST }^{\text {b }} \\
\text { (days) }\end{array}$ & $\begin{array}{c}\text { Mortality a } \\
(\%)\end{array}$ & $\begin{array}{l}\text { AST b } \\
\text { (days) }\end{array}$ & $\begin{array}{l}\text { Mortality a } \\
\text { (\%) }\end{array}$ & $\begin{array}{l}\mathrm{AST}^{\mathrm{b}} \\
\text { (days) }\end{array}$ \\
\hline Control & $11.7 \pm 4.2^{\mathrm{a}}$ & $7.5 \pm 0.2^{a}$ & $12.5 \pm 12.5^{\mathrm{a}}$ & $6.9 \pm 0.7^{a}$ & $70.8 \pm 7.7^{b}$ & $3.3 \pm 0.6^{a}$ \\
\hline Colonized & $45.0 \pm 1.4^{b}$ & $6.6 \pm 0.2^{b}$ & $58.3 \pm 12.4^{b}$ & $5.2 \pm 0.6^{\mathrm{a}}$ & $87.5 \pm 8.5^{b}$ & $3.1 \pm 0.5^{\mathrm{a}}$ \\
\hline
\end{tabular}

a Within the same column, means with the same letter are not significantly different to each other $\left(\chi^{2}\right.$ test, $\left.p \leq 0.05\right)$ according to the generalized linear model. Data are expressed as mean \pm SE. ${ }^{b}$ AST: Average survival time was limited to 8 days. Within the same column, means with the same letter are not significantly different to each other $(p \leq 0.05)$ according to the log-rank test. Data are expressed as mean $\pm S E .{ }^{c} n_{\text {control }}=120$ and $n_{\text {colonized }}=120 .{ }^{d}$ $\mathrm{n}_{\text {control/non-damaged }}=24, \mathrm{n}_{\text {control } / \text { damaged }}=24, \mathrm{n}_{\text {colonized/non-damaged }}=24, \mathrm{n}_{\text {colonized } / \text { damaged }}=24$.
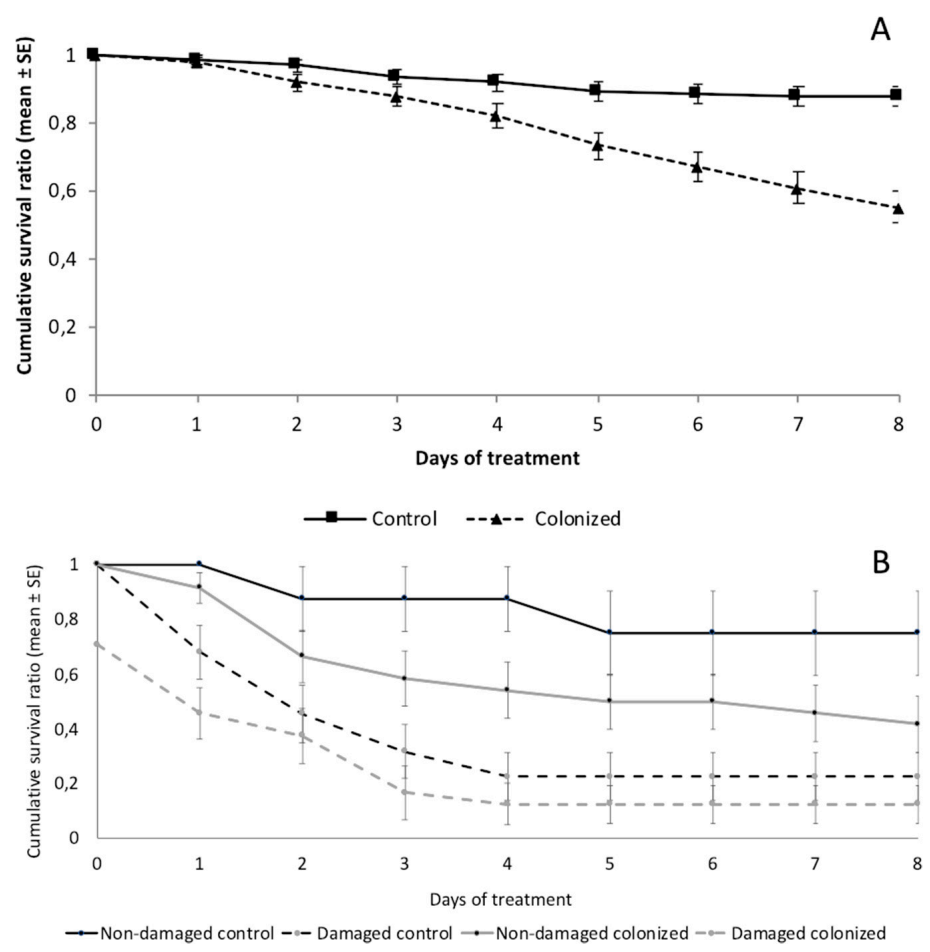

Figure 2. Cumulative survival ratio (mean \pm SE) of $S$. littoralis larvae fed on $(A)$ control $(n=120)$ and Metarhizium-colonized melon discs $(\mathrm{n}=120),(\mathbf{B})$ control and Metarhizium-colonized plants in experiments with whole plants (non-damaged) $\left(n_{\text {control }}=24, n_{\text {colonized }}=24\right.$ ) and plants damaged by tearing a non-treated leaf (damaged) $\left(\mathrm{n}_{\text {control }}=24, \mathrm{n}_{\text {colonized }}=24\right)$. 
There were significant treatment $\left(\mathrm{F}_{1,1192}=238.8, p=0.0011\right)$, time-related $\left(\mathrm{F}_{7,1192}=1065.0\right.$, $p<0.0001)$ and treatment-time interaction $\left(\mathrm{F}_{7,1192}=448.6, p<0.0001\right)$ differences in the mean area $\left(\mathrm{mm}^{2}\right)$ of the control and Metarhizium-colonized discs consumed by $S$. littoralis larvae during the 8-day experiment; the larvae fed on discs with fungal colonization consuming a mean area of $13.6 \pm 0.3 \mathrm{~mm}^{2}$ of leaf disc per capita and day and the larvae fed on control discs consuming a mean area of $14.6 \pm 0.3 \mathrm{~mm}^{2}$ of leaf disc per capita and day. In general, more of the control discs than the Metarhizium-colonized discs were consumed daily, except on the second day, when more of the Metarhizium-colonized discs than the control discs were consumed (Figure 3). The disc consumption per capita in both treatments was reduced during days 6 to 8 , but significant differences were found between the treatments (Figure 3).

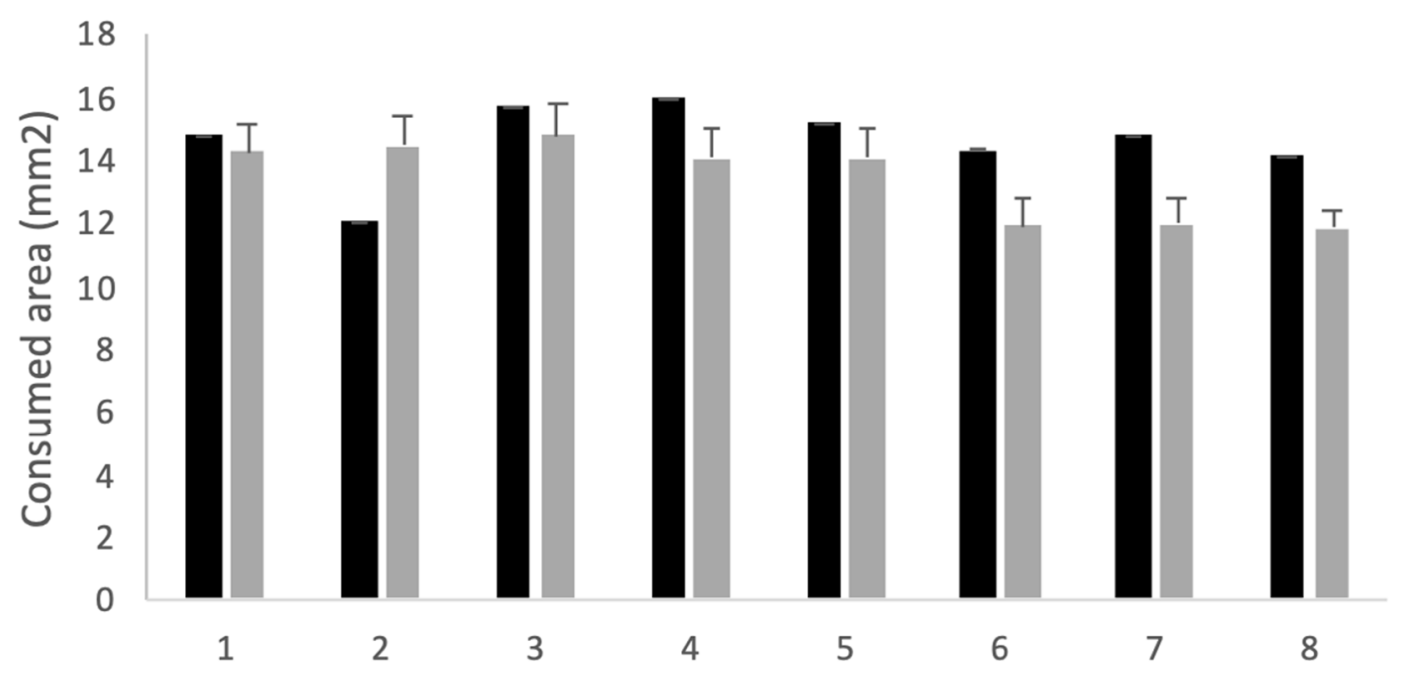

Days of treatment

- Control Colonized

Figure 3. Mean area $\left(\mathrm{mm}^{2}\right)$ of control and Metarhizium-colonized discs consumed by S. littoralis larvae during the experiment (8 days). Bars indicate \pm SE. $\mathrm{n}_{\text {control }}=720, \mathrm{n}_{\text {colonized }}=720$.

\subsubsection{Sublethal Reproductive Effects of Exposure of S. littoralis to Metarhizium-Colonized Melon Discs}

The ingestion of Metarhizium-colonized discs had a significant effect on the fecundity $\left(\chi^{2}(1)=161.95, p<0.001\right)$ and fertility $\left(\chi^{2}(1)=242.28, p<0.001\right)$ of the females that emerged from the surviving pupae developing from larvae feeding on treated melon discs $\left(\mathrm{n}_{\mathrm{control}}=26\right.$ females, $\mathrm{n}_{\text {colonized }}=16$ females). The highest mean value of fecundity was $221.3 \pm 75.0$ eggs per female emerging from surviving pupae developing from larvae feeding on control melon discs, while the lowest fecundity value of $135.6 \pm 50.3$ eggs per female was found in the females emerging from pupae developing from larvae fed on fungus-colonized melon discs. The lowest mean egg fertility (as measured by emerged larvae) was 19.9\% for adults emerging from the fungal treatment, compared to $25.8 \%$ of egg fertility for the control treatment.

\subsubsection{Stress Induced via Caspase Activation Following the Ingestion of Metarhizium-Colonized Melon Discs}

Dead larvae identified following the ingestion of either Metarhizium-colonized of control discs did not show activity of caspases $1,3 / 7$, and 8, with means ranging from 17.1 to 19.0 RLU for larvae fed on Metarhizium-colonized discs and means between 17.7 and 19.2 RLU for larvae fed on control discs. 


\subsection{Effect of in Planta Exposure of S. littoralis to Metarhizium-Colonized Melon Leaves}

\subsubsection{Mortality and Food Consumption}

The percentage of fungal colonization on the Metarhizium-treated leaves was $95.0 \pm 3.4 \%$ at $48 \mathrm{~h}$, while the percentage of fungal colonization on the non-treated leaves from Metarhizium-treated plants was $5.8 \pm 1.8 \%$ (leaves distant from the inoculated ones). The control leaves did not show any signs of fungal colonization. Significant differences in mortality were found between treatments $\left(\chi^{2}(3)=27.2, p<0.001\right)$, with mortality rates of 12.5 and $70.8 \%$ for larvae fed on non-inoculated non-damaged plants versus non-inoculated damaged plants, respectively. However, the mortality rates of the larvae fed on Metarhizium-colonized plants were $58.3 \%$ and $87.5 \%$ for non-damaged and damaged plants, respectively, and Abbott mortalities of $45.8 \%$ and $16.7 \%$, respectively (Table 1 ). The average survival times also showed significant differences, ranging from 3.1 days for Metarhizium-colonized damaged plants to 6.9 days for the control and non-damaged plants (Table 1). In addition, the cumulative survival ratio significantly decreased in larvae fed on both Metarhizium-colonized and damaged plants (Figure 2B).

Neither M. brunneum colonization nor leaf damage had a significant impact on plant consumption $(\mathrm{H}=5.44, p=0.1422)$, with the leaf area consumed by $S$. littoralis larvae of $19.7 \pm 5.0 \mathrm{~mm}^{2}$ and $24.7 \pm 4.6 \mathrm{~mm}^{2}$ for non-damaged and damaged control plants, respectively, and $15.1 \pm 1.9 \mathrm{~mm}^{2}$ and $12.4 \pm 2.9 \mathrm{~mm}^{2}$ for non-damaged and damaged Metarhizium-colonized plants, respectively.

3.2.2. Stress Induced via Caspase Activation after the Exposure of S. littoralis to Metarhizium-Colonized Melon Leaves

Caspase 1 activity was not detected in larvae that died after exposure to either Metarhizium-colonized, non-damaged plants or non-colonized, damaged plant, with means ranging from 18.5 RLU for larvae fed on the controls to 18.8 RLU for larvae fed on Metarhizium-colonized, non-damaged plants.

\section{Discussion}

Several studies have evaluated the mortality of $S$. littoralis larvae after the ingestion of EPF-colonized plants $[3,17,30]$. However, this is the first attempt to elucidate the causes of this mortality and the effects of exposure to EPF-colonized plants both using leaf discs from colonized plants and in planta. In both scenarios, leaves treated with the M. brunneum EAMb 09/01-Su strain were endophytically colonized at $48 \mathrm{~h}$, at rates of $64.4 \%$ for sprayed leaves used to obtain leaf discs and $95.0 \%$ for brushed leaves used in planta. These values are slightly higher than those reported by Resquín-Romero et al. [3] following the spraying of leaf surfaces of melon plants with the same strain (approximately 50.0\% at $48 \mathrm{~h}$ ) and by Garrido-Jurado et al. [2] after brushing the fungus on melon leaves (approximately $70.0 \%$ at $48 \mathrm{~h}$ ), indicating good experimental conditions for endophytic colonization in which the strain expressed its high endophytic potential. In addition, the in planta experiment showed that this strain was able to enter the plant and colonize non-treated areas (5.8\% colonization), as previously reported after $96 \mathrm{~h}$ of treatment Garrido-Jurado et al. [2].

The mortality of $S$. littoralis larvae fed on Metarhizium-colonized discs was similar to that previously reported for the same strain [3], but in this case, the AST was slightly lower (6.6 days) than in the previous study (8.4 days), probably because of the higher colonization rates. Previous studies have shown variability in lepidopteran mortality after the ingestion of EPF-colonized plants. Some of these studies have reported high mortality values after the ingestion of colonized discs [25,31,32], but others have only shown a reduction in fitness $[33,34]$. In the current study, the fitness of S. littoralis larvae feeding on Metarhizium-colonized discs and adults emerging from pupae developing from surviving larvae was reduced in terms of food consumption and reproductive potential, respectively. This study showed that Metarhizium-colonized discs negatively affected feeding on melon plants. Similarly, McGee [33] and Russo et al. [31,35] reported a reduction in the consumed area of fungal-colonized 
plants by the noctuids Helicoverpa armigera (Hübner), H. gelotopoeon (Dyar) and Rachiplusia nu (Guenée). However, Viana et al. [36] and Allegrucci et al. [37] reported that noctuid larvae of H. gelotopoeon and gelechiid larvae of Tuta absoluta (Meyrick) preferred to feed on EPF-colonized discs.

Both the fecundity and fertility of females that emerged from surviving pupae that developed from larvae fed on Metarhizium-colonized discs were reduced compared to those of females that emerged from surviving pupae of larvae fed on control discs. In addition, the data obtained in the current work suggest low fertility of eggs laid by S. littoralis larvae fed on melon plants. The fecundity and fertility of $S$. littoralis females may be influenced by the host plant; in fact, cucurbitaceans are preferred plants for $S$. littoralis feeding but negatively affect insect reproductive parameters $[38,39]$. Our results were consistent with previous studies on lepidopteran pests showing a reduction in the lifespan and reproductive potential of insects fed on EPF-colonized plants or their offspring $[25,31,36]$. These studies also indicate that these effects could be produced as a result of secondary metabolite production or the induction of a systemic response in the colonized plants [31]. Resquín-Romero et al. [3] quantified destruxin A metabolite production on S. littoralis cadavers after the ingestion of Metarhizium-colonized discs, but the percentage of cadavers with destruxin A (11\%) could not entirely explain the lack of fungal outgrowth on dead larvae. Other studies have provided evidence of cellular death or apoptosis in the cadavers of insects fed on endophytically colonized plants [2] or insects that ingested Metarhizium conidia, inducing high expression levels of stress genes such as thiol peroxidase and heat shock proteins (HSPs), probably regulating caspase activation and subsequent insect death [22-24]. Notably, our results showed for the first time that the cellular death induced in S. littoralis cadavers was not caspase-mediated, as observed in aquatic insects such as mosquito larvae and the crustaceans D. pulex and A. magna. Other studies have revealed that apoptosis in insects may be induced by ribosome-inactivating proteins (RIPs) produced by plants against pathogens and insect pest, and RIPs have been demonstrated to show insecticidal activity and cause fitness reduction in several lepidopteran species [40].

In tritrophic insect-fungus-plant systems, both insects and fungi may induce several plant responses. Differences in the plant volatile profile and secretion of metabolites have been described after insect feeding and fungal infection, as has systemically-acquired resistance, herbivore-induced resistance and induced systemic resistance of plants, with the accumulation of jasmonate and salicylic acid and the activation of resistance genes [41,42]. These processes can be amplified when the host plant is a suboptimal food resource for the insect pest, as observed in our work, in which melon plants were clearly non-favorable for $S$. littoralis in terms of certain parameters of its life table, such as egg fertility [38,39]. In this context, Jaber and Vidal [25] suggested that the loss of volatiles or secretion of metabolites may be induced after mechanical damage to a plant (i.e., the collection of foliar discs). In our study, larval mortality in the in planta experiment was higher than that in the experiment with discs on both damaged and Metarhizium-colonized plants, probably due to the secretion of compounds such as phenols or saponins, which are known to be toxic to herbivores [43-45], and the alteration of hormone signaling after the induction of damage $[17,46]$. Similar results were obtained with third-instar S. littoralis larvae fed on young cotton leaves from damaged and control plants, in which the larvae fed on damaged plants died by day 7 ( $87.5 \%$ mortality), and those fed on control plants pupated successfully, probably due to a reduction in palatability after foliar damage [47,48]. However, the area consumed by the $S$. littoralis larvae on damaged and Metarhizium-colonized plants was approximately the same. In this respect, there is no consensus about the potential of damaged or inoculated plants to act as a feeding deterrent [25,49]. This might be due to the few tritrophic studies performed thus far.

\section{Conclusions}

The present work reveals the occurrence of intermediate larval mortality levels related to the foliar application of the entomopathogenic endophytic fungus $M$. brunneum that were not associated with fungal outgrowth and were not caspase mediated. This work also shows the existence of significant sublethal effects of food consumption by larvae challenged by the fungal endophyte when feeding 
on colonized leaves and effects on the reproduction (female fecundity and egg fertility) of the adults emerging from pupae developing from surviving larvae. Experiments performed with foliar discs provide a biased analysis of this scenario due to the prior damage caused to the plant. The data from this research should be supplemented by the measurement of secreted metabolites, emitted volatiles and the regulation of plant hormones, and the reaction of the immune system of the insects after the ingestion of colonized plants under a scenario involving whole plants.

Author Contributions: Conceptualization, I.G.-J. and E.Q.-M.; Investigation, I.G.-J., D.M.-M. and P.S.-B.; Supervision, I.G.-J. and E.Q.-M.; Writing—original draft, I.G.-J.; Writing-review and editing, I.G.-J., D.M.-M., P.S.-B. and E.Q.-M. All authors have read and agreed to the published version of the manuscript.

Funding: This research was supported by the Programa Operativo FEDER Andalucía 2014-2020 UCO-FEDER 18 REF. 1253915.

Acknowledgments: The authors wish to thank Tariq Butt (Swansea University, UK) for his suggestions, and Maria Victoria Paredes Perez and Rafael de la Cueva Revuelta for their excellent technical assistance.

Conflicts of Interest: The authors declare no conflict of interest.

\section{References}

1. Quesada-Moraga, E.; Yousef-Naef, M.; Garrido-Jurado, I. Advance in the use of entomopathogenic fungi as biopesticides in suppresing crop insect pests. In Biopesticides for Sustainable Agriculture; Birch, N., Glare, T., Eds.; Burleigh Dodds Science Publishing: Cambridge, UK, 2020; pp. 63-98.

2. Garrido-Jurado, I.; Resquín-Romero, G.; Amarilla, S.P.; Ríos-Moreno, A.; Carrasco, L.; Quesada-Moraga, E. Transient endophytic colonization of melon plants by entomopathogenic fungi after foliar application for the control of Bemisia tabaci Gennadius (Hemiptera: Aleyrodidae). J. Pest Sci. 2017, 90, 319-330. [CrossRef]

3. Resquín-Romero, G.; Garrido-Jurado, I.; Delso, C.; Ríos-Moreno, A.; Quesada-Moraga, E. Transient endophytic colonizations of plants improve the outcome of foliar applications of mycoinsecticides against chewing insects. J. Invertebr. Pathol. 2016, 136, 23-31. [CrossRef] [PubMed]

4. Quesada-Moraga, E.; Muñoz-Ledesma, J.; Santiago-Alvarez, C. Systemic Protection of Papaver somniferum L. against Iraella luteipes (Hymenoptera: Cynipidae) by an Endophytic Strain of Beauveria bassiana (Ascomycota: Hypocreales). Environ. Entomol. 2009, 38, 723-730. [CrossRef] [PubMed]

5. Vega, F.E. The use of fungal entomopathogens as endophytes in biological control: A review. Mycologia 2018, 110, 4-30. [CrossRef]

6. Mantzoukas, S.; Eliopoulos, P.A. Endophytic entomopathogenic fungi: A valuable biological control tool against plant pests. Appl. Sci. 2020, 10, 360. [CrossRef]

7. Russell, D.A.; Radwan, S.M.; Irving, N.S.; Jones, K.A.; Downham, M.C.A. Experimental assessment of the impact of defoliation by Spodoptera littoralis on the growth and yield of Giza '75 cotton. Crop Prot. 1993, 12, 303-309. [CrossRef]

8. EPPO. PM 7/124 (1) Spodoptera littoralis, Spodoptera litura, Spodoptera frugiperda, Spodoptera eridania. EPPO Bull 2015, 45, 410-444. [CrossRef]

9. EPPO. EPPO Global Database. Available online: http://gd.eppo.int (accessed on 22 November 2018).

10. Mosallanejad, H.; Smagghe, G. Biochemical mechanisms of methoxyfenozide resistance in the cotton leafworm Spodoptera littoralis. Pest Manag. Sci. 2009, 65, 732-736. [CrossRef]

11. Siegwart, M.; Graillot, B.; Lopez, C.B.; Besse, S.; Bardin, M.; Nicot, P.C.; Lopez-Ferber, M. Resistance to bio-insecticides or how to enhance their sustainability: A review. Front. Plant Sci. 2015, 6, 1-19. [CrossRef]

12. Quesada-Moraga, E.; Carrasco-Diaz, J.A.; Santiago-Alvarez, C. Insecticidal and antifeedant activities of proteins secreted by entomopathogenic fungi against Spodoptera littoralis (Lep., Noctuidae). J. Appl. Entomol. 2006, 130, 442-452. [CrossRef]

13. Sahab, A.F.; Sabbour, M.M. Virulence of four entomopathogenic fungi on some cotton pests with special reference to impact of some pesticides, nutritional and environmental factors on fungal growth. Egypt. J. Biol. Pest Control 2011, 21, 61-67.

14. Resquín-Romero, G.; Garrido-Jurado, I.; Quesada-Moraga, E. Combined use of entomopathogenic fungi and their extracts for the control of Spodoptera littoralis (Boisduval) (Lepidoptera: Noctuidae). Biol. Control 2016, 92, 101-110. [CrossRef] 
15. Garrido-Jurado, I.; Resquín-Romero, G.; Yousef-Naef, M.; Riós-Moreno, A.; Quesada-Moraga, E. Soil drenching with entomopathogenic fungi for control of the soil-dwelling life stages and adults of the same generation of Spodoptera littoralis (Boisd.) (Lepidoptera: Noctuidae). Bull. Entomol. Res. 2020, 110, 242-248. [CrossRef] [PubMed]

16. Miranda-Fuentes, P.; Quesada-Moraga, E.; Aldebis, H.K.; Yousef-Naef, M. Compatibility between the endoparasitoid Hyposoter didymator and the entomopathogenic fungus Metarhizium brunneum: A laboratory simulation for the simultaneous use to control Spodoptera littoralis. Pest Manag. Sci. 2020, 76, 1060-1070. [CrossRef] [PubMed]

17. Sánchez-Rodríguez, A.R.; Raya-Díaz, S.; Zamarreño, Á.M.; García-Mina, J.M.; del Campillo, M.C.; Quesada-Moraga, E. An endophytic Beauveria bassiana strain increases spike production in bread and durum wheat plants and effectively controls cotton leafworm (Spodoptera littoralis) larvae. Biol. Control 2018, 116, 90-102. [CrossRef]

18. El Husseini, M.M.M. Efficacy of the entomopathogenic fungus, Metarhizium anisopliae (Metsch.), against larvae of the cotton leafworm, Spodoptera littoralis (Boisd.) (Lepidoptera: Noctuidae), under laboratory conditions. Egypt. J. Biol. Pest Control 2019, 29, 4-6. [CrossRef]

19. Hussein, H.M.; Zemek, R.; Habuštová, S.O.; Prenerová, E.; Adel, M.M. Laboratory evaluation of a new strain CCM 8367 of Isaria fumosorosea (syn. Paecilomyces fumosoroseus) on Spodoptera littoralis (Boisd.). Arch. Phytopathol. Plant Prot. 2013, 46, 1307-1319. [CrossRef]

20. Shaurub, E.S.H.; Reyad, N.F.; Abdel-Wahab, H.A.; Ahmed, S.H. Mortality and nematode production in Spodoptera littoralis larvae in relation to dual infection with Steinernema riobrave, Heterorhabditis bacteriophora, and Beauveria bassiana, and the host plant. Biol. Control 2016, 103, 86-94. [CrossRef]

21. Batta, Y.A. Efficacy of endophytic and applied Metarhizium anisopliae (Metch.) Sorokin (Ascomycota: Hypocreales) against larvae of Plutella xylostella L. (Yponomeutidae: Lepidoptera) infesting Brassica napus plants. Crop Prot. 2013, 44, 128-134. [CrossRef]

22. Butt, T.M.; Greenfield, B.P.J.; Greig, C.; Maffeis, T.G.G.; Taylor, J.W.D.; Piasecka, J.; Dudley, E.; Abdulla, A.; Dubovskiy, I.M.; Garrido-Jurado, I.; et al. Metarhizium anisopliae pathogenesis of mosquito larvae: A verdict of accidental death. PLoS ONE 2013, 8, e81686. [CrossRef]

23. Alkhaibari, A.M.; Carolino, A.T.; Yavasoglu, S.I.; Maffeis, T.; Mattoso, T.C.; Bull, J.C.; Samuels, R.I.; Butt, T.M. Metarhizium brunneum Blastospore Pathogenesis in Aedes aegypti Larvae: Attack on Several Fronts Accelerates Mortality. PLoS Pathog. 2016, 12. [CrossRef] [PubMed]

24. Garrido-Jurado, I.; Alkhaibari, A.; Williams, S.R.; Oatley-Radcliffe, D.L.; Quesada-Moraga, E.; Butt, T.M. Toxicity testing of Metarhizium conidia and toxins against aquatic invertebrates. J. Pest Sci. 2016, 89, 557-564. [CrossRef]

25. Jaber, L.R.; Vidal, S. Fungal endophyte negative effects on herbivory are enhanced on intact plants and maintained in a subsequent generation. Ecol. Entomol. 2010, 35, 25-36. [CrossRef]

26. War, A.R.; Paulraj, M.G.; Ahmad, T.; Buhroo, A.A.; Hussain, B.; Ignacimuthu, S.; Sharma, H.C. Mechanisms of plant defense against insect herbivores. Plant Signal. Behav. 2012, 7, 1306-1320. [CrossRef]

27. Santiago-Álvarez, C. Virus de Insectos: Multiplicación, Aislamiento y Bioensayo de Baculovirus; Fundación Juan March: Madrid, Spain, 1977.

28. Seifert, K.; Morgan-Jones, G.; Gams, W.; Kendrick, B. The Genera of Hyphomycetes; CBS-KNAW Fungal Biodiversity Centre: Utrecht, The Netherlands, 2011; Volume 9.

29. Courtiade, J.; Pauchet, Y.; Vogel, H.; Heckel, D.G. A comprehensive characterization of the caspase gene family in insects from the order Lepidoptera. BMC Genom. 2011, 12. [CrossRef]

30. Miranda-Fuentes, P.; Yousef-Yousef, M.; Valverde-García, P.; Rodríguez-Gómez, I.M.; Garrido-Jurado, I.; Quesada-Moraga, E. Endophytic Entomopathogenic Fungus-Mediated Tritrophic Interactions between the Generalist Carterpillar Spodoptera Littoralis and the Parasitoid Hyposoter Didymator; 2020; under review.

31. Russo, M.L.; Scorsetti, A.C.; Vianna, M.F.; Allegrucci, N.; Ferreri, N.A.; Cabello, M.N.; Pelizza, S.A. Effects of endophytic Beauveria bassiana (Ascomycota: Hypocreales) on biological, reproductive parameters and food preference of the soybean pest Helicoverpa gelotopoeon. J. King Saud Univ.-Sci. 2019, 31, 1077-1082. [CrossRef]

32. Kuchár, M.; Glare, T.R.; Hampton, J.G.; Dickie, I.A.; Christey, M.C. Virulence of the plant-associated endophytic fungus Lecanicillium muscarium to diamondback moth larvae. N. Z. Plant Prot. 2019, 72, 253-259. [CrossRef] 
33. McGee, P.A. Reduced growth and deterrence from feeding of the insect pest Helicoverpa armigera associated with fungal endophytes from cotton. Aust. J. Exp. Agric. 2002, 42, 995-999. [CrossRef]

34. Pelizza, S.A.; Mariottini, Y.; Russo, L.M.; Vianna, M.F.; Scorsetti, A.C.; Lange, C.E. Beauveria bassiana (Ascomycota: Hypocreales) introduced as an endophyte in corn plants and its effects on consumption, reproductive capacity, and food preference of Dichroplus maculipennis (Orthoptera: Acrididae: Melanoplinae). J. Insect Sci. 2017, 17, 1-6. [CrossRef]

35. Russo, M.L.; Scorsetti, A.C.; Vianna, M.F.; Cabello, M.; Ferreri, N.; Pelizza, S. Endophytic effects of Beauveria bassiana on corn (Zea mays) and its herbivore, Rachiplusia nu (lepidoptera: Noctuidae). Insects 2019, 10, 110. [CrossRef]

36. Vianna, F.; Pelizza, S.; Russo, L.; Allegrucci, N.; Scorsetti, A. Endophytic Beauveria bassiana (Ascomycota: Hypocreales) alters Helicoverpa gelotopoeon's (D.) (Lepidoptera: Noctuidae) life cycle and reproductive parameters. J. Plant Prot. Res. 2018, 58, 321-327. [CrossRef]

37. Allegrucci, N.; Velazquez, M.S.; Russo, M.L.; Perez, E.; Scorsetti, A.C. Endophytic colonisation of tomato by the entomopathogenic fungus Beauveria bassiana: The use of different inoculation techniques and their effects on the tomato leafminer Tuta absoluta (Lepidoptera: Gelechiidae). J. Plant Prot. Res. 2017, 57, 331-337. [CrossRef]

38. Dimetry, N.Z. Further Studies on the Host Plant Preference of Spodoptera littoralis Boisd. (Lepid., Noctuidae). Z. Für Angew. Entomol. 1972, 71, 350-355. [CrossRef]

39. Makkar, A.W.; Al-Shannaf, H.M.H.; El-Hamaky, M.A.; Sokkar, A.L. Life Table Parameters of the Cotton Leaf-Worm, Spodoptera Littoralis (Boisd.), on Different Vegetable Host Plants. J. Plant Prot. Pathol. 2015, 6, 597-603. [CrossRef]

40. Zhu, F.; Zhou, Y.K.; Ji, Z.L.; Chen, X.R. The plant ribosome-inactivating proteins play important roles in defense against pathogens and insect pest attacks. Front. Plant Sci. 2018, 9, 1-14. [CrossRef]

41. González-Mas, N.; Sánchez-Ortiz, A.; Valverde-García, P.; Quesada-Moraga, E. Effects of endophytic entomopathogenic ascomycetes on the life-history traits of Aphis gossypii Glover and its interactions with melon plants. Insects 2019, 10, 165. [CrossRef]

42. Raad, M.; Glare, T.R.; Brochero, H.L.; Müller, C.; Rostás, M. Transcriptional reprogramming of Arabidopsis thaliana defence pathways by the entomopathogen Beauveria bassiana correlates with resistance against a fungal pathogen but not against insects. Front. Microbiol. 2019, 10, 1-17. [CrossRef]

43. Adel, M.M.; Sehnal, F.; Jurzysta, M. Effects of alfalfa saponins on the moth Spodoptera littoralis. J. Chem. Ecol. 2000, 26, 1065-1078. [CrossRef]

44. Senthil, V.; Ramasamy, P.; Elaiyaraja, C.; Ramola Elizabeth, A. Some Phytochemical Prosperities Affected by the Infection of Leaf Spot Disease of Cucumis sativus (Linnaeus) Caused by Penicillium notatum. Afr. J. Basic Appl. Sci. 2010, 2, 64-70.

45. Haldhar, S.M.; Samadia, D.K.; Bhargava, R.; Choudhary, B.R.; Singh, D. Host plant accessions determine bottom-up effect of snapmelon (Cucumis melo var. momordica) against melon fly (Bactrocera cucurbitae (coquillett)). Breed. Sci. 2018, 68, 499-507. [CrossRef]

46. Contreras-Cornejo, H.A.; Macías-Rodríguez, L.; del-Val, E.; Larsen, J. The root endophytic fungus Trichoderma atroviride induces foliar herbivory resistance in maize plants. Appl. Soil Ecol. 2018, 124, 45-53. [CrossRef]

47. Alborn, H.T.; Röse, U.S.R.; McAuslane, H.J. Systemic induction of feeding deterrents in cotton plants by feeding of Spodoptera spp. larvae. larvae. J. Chem. Ecol. 1996, 22, 919-932. [CrossRef] [PubMed]

48. Anderson, P.; Alborn, H. Effects on oviposition behaviour and larval development of Spodoptera littoralis by herbivore-induced changes in cotton plants. Entomol. Exp. Appl. 1999, 92, 45-51. [CrossRef]

49. Jallow, M.F.A.; Dugassa-Gobena, D.; Vidal, S. Indirect interaction between an unspecialized endophytic fungus and a polyphagous moth. Basic Appl. Ecol. 2004, 5, 183-191. [CrossRef]

(C) 2020 by the authors. Licensee MDPI, Basel, Switzerland. This article is an open access article distributed under the terms and conditions of the Creative Commons Attribution (CC BY) license (http://creativecommons.org/licenses/by/4.0/). 